Management international

International Management

Gestiòn Internacional

Job Satisfaction, Turnover Intention and Work Performance in Chinese Family Enterprises

Satisfaction au travail, intention du roulement et performance au travail dans les entreprises familiales chinoises

Satisfacción Laboral, Intención de Rotación y Rendimiento Laboral en Empresas Familiares Chinas

Xiaobin Shu, Yeming (Yale) Gong, Jie Xiong et Xin Hu

Volume 22, numéro 2, hiver 2018

URI : https://id.erudit.org/iderudit/1058163ar

DOI : https://doi.org/10.7202/1058163ar

Aller au sommaire du numéro

Éditeur(s)

HEC Montréal

Université Paris Dauphine

ISSN

1206-1697 (imprimé)

1918-9222 (numérique)

Découvrir la revue

Citer cet article

Shu, X., Gong, Y. (., Xiong, J. \& Hu, X. (2018). Job Satisfaction, Turnover Intention and Work Performance in Chinese Family Enterprises. Management international / International Management / Gestiòn Internacional, 22(2), 84-95. https://doi.org/10.7202/1058163ar
Résumé de l'article

Basé sur une enquête de 121 entreprises familiales en Chine, nos résultats montrent que la relation entre la satisfaction au travail et l'intention de rotation est non-significative pour les membres de la famille, mais significative pour les autres. De plus, nos résultats indiquent que l'effet de la satisfaction au travail sur le rendement au travail est moins important pour les membres de la famille, mais plus important pour les non-membres de la famille. Nos résultats montrent en outre que l'occupation d'un poste de direction modère l'influence de l'appartenance à la famille dans les principaux effets mentionnés ci-dessus.
Tous droits réservés (c) Management international / International Management / Gestión Internacional, 2018
Ce document est protégé par la loi sur le droit d'auteur. L’utilisation des services d'Érudit (y compris la reproduction) est assujettie à sa politique d'utilisation que vous pouvez consulter en ligne.

https://apropos.erudit.org/fr/usagers/politique-dutilisation/ 


\section{Job Satisfaction, Turnover Intention and Work Performance in Chinese Family Enterprises*}

\section{Satisfaction au travail, intention du roulement et performance au travail dans les entreprises familiales chinoises}

\section{Satisfacción Laboral, Intención de Rotación y Rendimiento Laboral en Empresas Familiares Chinas}

\author{
XIAOBIN SHU \\ Central China \\ Normal University
}

\author{
YEMING(YALE) GONG \\ Emlyon business school
}

JIE XIONG

Rennes School of Business

\author{
XIN HU \\ Central China \\ Normal University
}

\section{RÉSUMÉ}

Basé sur une enquête de 121 entreprises familiales en Chine, nos résultats montrent que la relation entre la satisfaction au travail et l'intention de rotation est non-significative pour les membres de la famille, mais significative pour les autres. De plus, nos résultats indiquent que l'effet de la satisfaction au travail sur le rendement au travail est moins important pour les membres de la famille, mais plus important pour les non-membres de la famille. Nos résultats montrent en outre que l'occupation d'un poste de direction modère l'influence de l'appartenance à la famille dans les principaux effets mentionnés ci-dessus.

Mots-Clés : Entreprises familiales; Satisfaction au travail; Intention de rotation; Le rendement du travail; Membres de la famille; Poste de direction; Entreprise chinoise.

\section{RESUMEN}

Basándonos en 121 empresas familiares en China, nuestros resultados muestran que la relación entre la satisfacción laboral y la intención de rotación es insignificante para los miembros de la familia, pero significativa para los que no lo son. Nuestros resultados también indican que el efecto de satisfacción laboral en el rendimiento laboral es menos importante para los miembros de la familia, pero más significativo para los que no lo son. Nuestros resultados muestran además que el acceso a un puesto de dirección reduce el peso de la pertenencia familiar en los principales efectos anteriormente mencionados.

Palabras Clave: Empresas familiares; Satisfacción laboral; Intención de rotación; Rendimiento laboral; Pertenencia familiar; Puestos directivos; Negocios chinos.

Keywords: Family enterprises; Job satisf tion; Turnover intention; Work performance; Family membership; Managerial position; Chinese business.

$\mathrm{F}_{\mathrm{i}}^{\mathrm{a}}$ amily enterprises have become a common form of organization in the modern economy. In emerging markets like China, during the process of transformation from a planned economy to a market economy, family enterprises developed rapidly. From 1993 to 2004, the number of Chinese family enterprises grew by $28.9 \%$, with the total number of units 3.0055 million. In the same period, the registered capital of family enterprises increased from 68.1 billion to 3.5305 trillion Chinese yuan, an increase by a factor of 52 . Meanwhile, the number of employees increased from 3.72 million to 42.99 million, by a factor of nearly twelve. More importantly, the value of export commodities increased from 42.2 billion to 2,008.3 billion Chinese yuan (Zhang, 2005). In the 2007 Forbes “China's Richest" list, the percentage of family enterprises among the Top 100 enterprises was as high as $84 \%$.
Compared with the modern enterprise systems, the family enterprise system has a dual nature of both households and firms. In the relationship between the family system and the enterprise system, people on their own, family members and friends, acquaintances, and strangers are intertwined (Berrone, Cruz and Gomez-Mejia, 2012). This typifies the Chinese characteristics of personal relationships in the family enterprises. Especially in Chinese family enterprises, the allocation of human resources is based primarily on blood, kinship, and geographic distance (Hwang, 2012). This leads to the core employees of important positions mostly consisting of family members; thus, the relationship between employees and owners in these family enterprises is special. The coexistence of family members and non-family members has brought a series of challenges in both governance and human-resource

* Acknowledgement:

We gratefully acknowledge the editor and the referees for their valuable comments. This work was supported by the National Social Science Foundation of China (No. 16ZDA013) and National Science Foundation of China (\#71772142). 
management in Chinese family enterprises (Sharma, Chrisman and Chua, 1997).

In such family enterprises, family members are often treated favorably, while others are rarely promoted or asked to hold core management positions. This may lead to the lower job satisfaction of non-family member employees and even a high rate of staff turnover (Dyer, 2006). Some data show that the turnover rate of employees in small- and medium-sized Chinese private enterprises (the majority of which are family enterprises) is as high as $50 \%$, and that middle and senior managers, as well as technical personnel, are the main employees experiencing turnover. The high turnover rate of employees in family enterprises, especially the loss of key talents, not only increases the costs of human-resources management but also leads to loss of knowledge. Spector (1997) points out that an employee's job satisfaction has a strong affinity with their job performance and absenteeism and with the staff's physical and mental health.

Therefore, for family enterprises in China, understanding the key role of family membership is important for current family-enterprise management and theorists (Wong, 1985). Knowing well how different family members and non-family members behave can lead to increase employees' job satisfaction, which will further help to reduce the turnover rate and improve work performance. The main objective of this research is to examine the influence of individuals' job satisfaction on their turnover intention and work performance in Chinese family enterprises. We examine the main effects of job satisfaction of all ordinary employees and managers on their turnover intention and work performance. In addition to the main effects mentioned above, we also evaluate the moderating roles of family membership (i.e. family members and non-family members) and of managerial position (i.e. ordinary employees and managers) on these main effects. More interestingly, we test the moderation of managerial position and family membership on the main effects. By doing so, it is expected that we will enrich our understanding of management of the individuals' job satisfaction and finally of how to improve work performance in family enterprises.

\section{Theory and Hypothesis Development}

\section{Job SATISFACTION AND TURNOVER INTENTION}

Some scholars have discovered a negative correlation between job satisfaction and an employee's turnover intention (Lee, Holtom, Mcdaniel and Hill, 1999; Trevor, 2001; DeConinck and Stilwell, 2004). Some other researchers continue to research the relationship between job satisfaction and turnover intention of employees-for example, moderators such as gender, roles, experience, and organizational climate. For instance, McNeilly and Goldsmith (1991) summarize that gender plays an important role in the relationship between job satisfaction and turnover intention. The authors point out that both female and male employees leave their current sales positions because of dissatisfaction with different aspects of their jobs. For example, satisfaction with achievement indicators has more influence on men's turnover than women's, while satisfaction with interpersonal relationships has more influence on women. Jones, Chonko, Rangarajan and Roberts (2007) conclude that role overload, as well as experience, is important in the negative relationship between job satisfaction and turnover intention. The authors state that job satisfaction and turnover intention for more experienced salespeople are more adversely affected by role overload than are less experienced salespersons. Schwepker (2001) finds that when the salespeople perceive a more ethical climate within the organization, they have a higher level of job satisfaction, more commitment to their organization, and a lower intention to leave. Valentine, Greller and Richtermeyer (2006) propose that perceived organizational supports can mediate the relationships between an ethical context and job satisfaction and turnover intention. Perceived organizational support is associated with increased job satisfaction and decreased turnover, and job satisfaction is negatively related to turnover intention.

From a perspective of agency theory, the owners of family enterprises evaluate family members and non-family members differently, including both the employees and managers. For instance, the wages of a manager depend on short-term performance, which is determined by short-term measures (Antia, Pantzalis and Park, 2010). If a non-family member manager wants to increase his or her wages or move to a new employer, this non-family member manager must achieve high performance in these areas. The personal goals of non-family member managers might differ strongly from those of family-member managers or of family owners. The goals of the business-owning family are often long-term-oriented (Le Breton-Miller and Miller, 2006; Block, 2010) and may differ from those of non-family enterprises (Guzzo and Abbott, 1990; Lee and Rogoff, 1996).

This will lead to different perceptions at the managerial level, depending on whether the managers are family members. Put in other words, family membership is important in the management of family enterprises. As a consequence, managers' perception of job security and job satisfaction follow the membership per se. Solving the conflicted demands between principles and agents may help family enterprises to reduce misunderstandings and management costs (Dyer, 2006). It is also beneficial to the overall integration of employees into the family enterprises and to the increase of job satisfaction, therefore, to reduce potential turnover intentions (Khanin, Turel and Mahto, 2012).

Quinn, Staines, and McCullough (1974) argue that managers have higher satisfaction with their work, because managers are experienced in their own careers at getting better jobs. Muchinsk and Morrow (1980) conclude that the factors affecting turnover intention can be expressed in three dimensions: work-related factors, economic-opportunity factors, and individual factors. Among these factors, individual factors include professional characteristics, such as position. Naresh (2001) also finds that individual factors are among the reasons for employees' turnover intentions. More importantly, the author points out that the voluntarily turnover intention of management is higher than that of ordinary employees. Yu (2001) also finds that gender, age, culture level, population, and occupational variables such as position level and office term have a significant effect on job satisfaction. Chen and Zhou (2003) examine the Macao civil servants' job satisfaction at medium and high levels. This researcher identifies that managers have higher job satisfaction than ordinary employees. These studies conclude that holding a managerial position rather than that of an ordinary employee is an important factor in the correlation between job satisfaction 
and turnover intention. In family enterprises in emerging economies, however, very few studies have focused on the influence of holding a managerial position in the relationship between job satisfaction and turnover intention when taking into account family membership (Wong, 1985).

\section{Job Satisfaction and Work Performance}

Scholars examined the relationship between job satisfaction and work performance in the past decades. The empirical results of such relationships, however, are mixed. The first group of literature shows a significant correlation between job satisfaction and work performance. Early scholars, such as Hochwarter et al. (1999), summarize the positive correlation between job satisfaction and performance. Later on, Judge, Thoresen, Bono and Patton (2001) show that the positive relationship between job satisfaction and work performance can also be moderated by other factors, such as the size and complexity of the work. In the research contexts of emerging markets, Li et al. (2005) conducted a case study of the Chinese Academy of Sciences and find that job satisfaction positively influences the performance of scientific research. In other words, the authors conclude that the higher the job satisfaction level, the higher the performance of the scientific research.

Another group of researchers identifies the reciprocal relationship between job satisfaction and work performance. Wanous (1974) examines job satisfaction from both internal and external perspectives. From an internal perspective, job satisfaction can promote work performance, while from an external perspective, job performance promotes job satisfaction. Later studies confirm the reciprocal relationship between job satisfaction and work performance discovered in the earlier research (Shore and Martin, 1989).

The last group of research finds no relationship between job satisfaction and work performance. Brayfield and Crockett (1955) studied employees' working attitudes and practical work efficiency for 40 years. The authors find that employees with high job satisfaction may achieve higher work performance, but that employees with low job satisfaction may also achieve higher work performance. Thereby, Brayfield and Crockett (1955) conclude that there is no significant correlation between job satisfaction and work performance. Later research by Iaffaldano and Muchinsky (1985) also points out that there is almost no connection between job satisfaction and work performance. A more recent study by Brashear et al. (2003) also concludes that there is no correlation between job satisfaction and work performance. These researchers do, however, identify a key moderator in the examined relationship: role ambiguity was negatively correlated with job satisfaction and job performance.

The aforementioned studies of the relationship between job satisfaction and work performance show mixed empirical results, which leave much unexplained phenomena. This means that additional efforts may be required to investigate the relationship, if any. Many scholars argue that the mixed results of the correlation between job satisfaction and work performance are due to important moderators, such as self-actualization, organizational commitment, role orientation, role ambiguity, job involvement, organizational commitment, goal setting, and authorization (Brashear et al., 2003; Demoussis and Giannakopoulos, 2007; Judge et al., 2010; Margolis and Myrskyla, 2011; Sieger, Bernhard and Frey, 2011; Millian, 2013).

These studies, however, did not differentiate the family enterprises from other kinds of organizations. In other words, the research on the potential relationship between job satisfaction and work performance in family enterprises is largely ignored. In addition, we know even less about the correlation between job satisfaction and work performance in those family enterprises in emerging countries, such as China. To fill in these gaps in the literature, therefore, in this study, we consider the potential correlation between job satisfaction and work performance in Chinese family enterprises. Considering the important roles of family membership and managerial position, we also pay attention to the potential moderating effects of these two factors in examining the relationship between job satisfaction and turnover intention, as well as the relationship between job satisfaction and work performance. In so doing, we expect to reveal insight into the governance of family enterprises in emerging markets.

\section{JOB SATISFACTION AND TURNOVER INTENTION IN CHINESE FAMILY ENTERPRISES}

We use agency theory and corporate-governance literature to examine the correlation between job satisfaction and turnover intention, by considering the moderating roles of family membership and managerial position. We focus on such potential relationships in the Chinese family enterprises. Previous studies (such as Carsten and Spector, 1987; Lee et al., 1999; Trevor, 2001; and DeConinck and Stilwell, 2004) show a negative relationship between job satisfaction and turnover intention. It is unclear, however, whether a negative relationship exists between the degree of employees' job satisfaction and their turnover intention in Chinese family enterprises.

In family enterprises, family members have a different perception of job satisfaction compared with non-family members (Berrone et al., 2012). Some family members may choose to work for their family enterprises because these family members think that doing so can better meet their aspirations and ambitions (Khanin et al., 2012). Some other family members, however, choose to work for their family enterprises because they believe their efforts could earn better returns compared with other jobs (Sharma, 2004). When there is higher job satisfaction, both family members and non-family members are less likely to change jobs. Once job satisfaction decreases, however, non-family members will have more flexibility in changing jobs, partly because the potential loss of non-family members will be less significant than the potential loss of family members when working outside of the family enterprises (Wong, 1985). Family members, in contrast, may sacrifice benefits in order to maintain family ties even when they are not satisfied with their jobs. This means that family members will be less likely to change their jobs even if they lose job satisfaction while working for family enterprises. Thus, family members show greater commitment to their positions within the family enterprises than do nonfamily members (Sharma and Irving, 2005).

Agency theory indicates that owners of family enterprises have different expectations of family-member managers and non-family member managers (Khanin et al., 2012). Although non-family members have more flexibility in their careers when 
outside opportunities are available, more capable non-family members may be more likely to stay with family enterprises. The main reason for this is that these non-family members can gain a better equity stake when compared with alternative work opportunities outside of the family enterprise (Khanin et al., 2012). For non-family members, such behaviors can help them to develop a "calculative commitment" (Sharma and Irving, 2005) in which non-family member managers can gain a deeper understanding of the family's goals and the significance of the roles, which can contribute to effectively managing a family enterprise (Hall and Nordqvist, 2008).

In family enterprises, managers accept more challenges and have a greater sense of achievement in the process of work activities (Sharma et al., 1997). On the one hand, when managers make suggestions to the company's strategic direction, the rational proposal is put forward by the company's business management. Management and executions will be adopted more easily by decision-makers and owners of the family enterprises. On the other hand, as leaders of divisions and departments, managers have more decision-making authority. This makes these managers more strongly engaged in the family enterprises. Ordinary employees may have limited chances to be involved in affecting management decisions. When the proposed suggestions or opinions of ordinary employees are not adopted by the management, the engagement of these employees will be poor. Therefore, in family enterprises, managerial positions can help to retain talents in the organizations. Moreover, for family members who occupying managerial positions, the turnover intention is lower than those non-family member ordinary employees.

To summarize, agency theory and corporate-governance literature indicate that job satisfaction will reduce the likelihood of turnover intention for family members and nonfamily members alike within family enterprises. The negative effects are more significant, however, for non-family member employees and managers, due to their lack of family commitment and greater flexibility when more attractive outside job opportunities become available. Managerial position also plays an important role, however, in helping family enterprises retain human talents, especially for those family members. Therefore, we formally state our hypothesis as:

Hypothesis 1a: The higher the degree of job satisfaction, the lower the turnover intention for both family members and nonfamily members.

Hypothesis 1b: Such a relationship (the main effect) is more significant for non-family members than for family members.

Hypothesis 1c: Such a relationship (the main effect) is more significant for managers than for ordinary employees.

Hypothesis 1d: The moderating effect of family membership in the relationship between degree of job satisfaction and turnover intention is more significant for managers than for ordinary employees.

\section{JOB SATISFACTION AND WORK PERFORMANCE IN CHINESE FAMILY ENTERPRISES}

Based on agency theory and corporate-governance literature, agents' efforts may not be easily presented to the family owners or founders without a channel such as family membership (Wong, 1985). Even if non-family members can show their contribution to family enterprise owners, these non-family members differ in management style and cognition (Block, 2011). Family enterprise owners try to motivate their employees via more charismatic behavior, while non-family member managers are more likely to make decisions based on logic and rational analysis rather than intuition (Dyer, 1989). Such differences may be due to organizational and occupational differences within family enterprises. Normally, family member managers grew up in the family and learned skills and practices exclusive to their family enterprise, but often without adequate experience outside the company.

While non-family members are not bonded by family membership as family members are, ordinary employees and managers of non-family members are more flexible when facing opportunities beyond the scope of the family (Khanin et al., 2012). When there is a misunderstanding or dissatisfaction with the tasks given, non-family members have more freedom to choose a career outside of the family enterprise. One partial reason is that, when moving from a family enterprise to an outside firm, the potential loss of nonfamily members will be less significant to the enterprise than that of family members (Wong, 1985). Family members may not change jobs, however, as their career path is likely to be more successful when working within the family enterprises. Due to such differences, the job satisfaction of non-family members relates more strongly to performance than does that of family members.

The satisfaction of managers is significantly higher than that of ordinary employees, particularly with respect to capable managers. It is mainly because managers' jobs are often more challenging than the content of ordinary employees' work; they can make decisions in their duties, and the sense of achievement in the work of top leaders is much higher than that of ordinary employees (Sharma et al., 1997). The other reason might be that managers' work environment and the quality of their treatment at work are much higher than ordinary employees'. The performance of ordinary employees differs across different scopes of work. Along with working experience, managers have accumulated abundant skills and knowledge, making them much more proficient at their work and improving their work performance (Khanin et al., 2012). In this case, work performance will vary with different hierarchies of the staffs in different family enterprises. For capable managers, once they adapt to the family enterprises, they can become more loyal to their positions, which will further improve their work performance within the company.

Moreover, for family-member managers in family enterprises, due to the strong family bonds and the position, these managers will be even more beneficial when working for their own family enterprises (Sharma, 2004). Compared to those family members without managerial positions, family-member managers can develop better career paths and knowledge, which will help them to better manage their daily activities and tasks. In the long run, such knowledge, including their understanding of the dedicated family enterprises and the 
advantages of family bonds, will further enhance their work performance, leading to higher individual achievements.

Therefore, we anticipate that job satisfaction and work performance are positively correlated in family enterprises among both family members and non-family members. In other words, higher job satisfaction leads to higher work performance in family enterprises. Such a relationship between job satisfaction and work performance, however, will be strongly influenced by family membership. Meanwhile, due to the characteristics of managerial positions, managers can be expected to have more significant effects on the correlation between job satisfaction and work performance. Due to the difference in job expectations and working conditions, products of an organizational hierarchy such as a managerial position also leads to different outcomes for people working in family enterprises. This may result in the divergent influence of job satisfaction and work performance between managers and ordinary employees in family enterprises. In particular, for family-member managers, there is an expectation of more loyalty to the family enterprises, which will eventually lead to better work performance than those family-member ordinary employees. We thereby formally propose the following hypothesis:

Hypothesis 2a: The higher the degree of job satisfaction, the higher the work performance for both family members and nonfamily members.

Hypothesis 2b: Such a relationship is more significant for non-family members than for family members.

Hypothesis 2c: Such a relationship (the main effect) is more significant for managers than for ordinary employees.

Hypothesis 2d: The moderating effect offamily membership in the relationship between degree of job satisfaction and work performance is more significant for managers than for ordinary employees.

\section{Methodology}

Before investigating family enterprises, we first present a measurable definition of family members. A core family member is defined as the owner or owner's partner, parent, brother, sister, son, or daughter. A close relative is an uncle, aunt, niece, or nephew. A distant relative indicates a relative who is not a close relative. Friends indicate members who have a close friendship with a core family member and close relatives: for example, their classmates, alumni, and neighbors (Dienesch and Liden, 1986).

\section{Research Design}

Before the formal investigation, we implemented a pilot test, which comprised a survey completed by 32 employees in 11 family enterprises in China. The pilot test shows a clear difference between the roles of family members and non-family members in these Chinese family enterprises. Moreover, such a difference may be important to the traditional view of employees' and executives' job satisfaction, job turnover intention, and job performance.

Given our main research interests, we try to understand the influence of family membership on job satisfaction, turnover intention, and work performance in Chinese family enterprises by considering the difference of managerial positions. More specifically, we decided to examine the role of family membership in the correlation between job satisfaction and turnover intention, as well as between job satisfaction and job performance, in Chinese family enterprises. We also consider managerial positions when studying the above-mentioned relationships. Therefore, a quantitative survey was implemented. To ensure a high response rate, a research team was recruited and assigned to the survey-collection processes. The research team was well trained for the research purposes, with adequate research skills and ethics.

FIGURE 1

The research model of this study

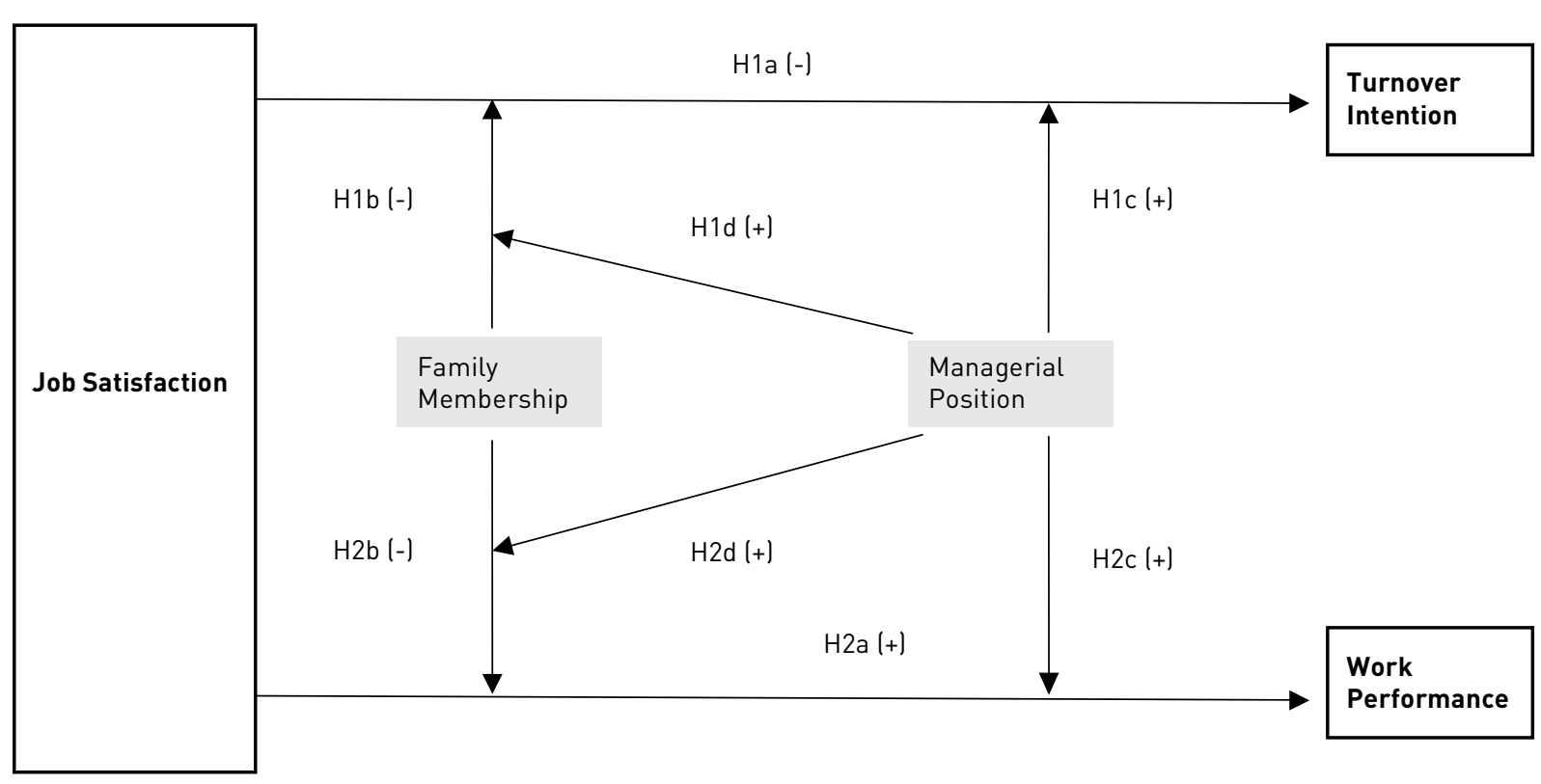




\section{VARIABLES}

This study relates to the concept of the three categories of job satisfaction, turnover intention, and work performance. The independent variable is job satisfaction. We have two dependent variables, turnover intention and work performance. We also consider two moderators, family membership (family members or non-family members) and managerial position (ordinary employees or managers). In order to ensure the validity and reliability of measurement tools, the formation of the initial questionnaire helped us to take established and validated scale based on existing literature. In order to control the effects of other variables on the research, this paper chose gender, age, work position, hierarchy, and industry as control variables. In our study, we conducted statistical analysis using SPSS20.0 and AMOS21.0. During our empirical tests, we paid particular attention to the reliability and validity of homologous error and multicollinearity problems. Meanwhile, we also verified the assumptions and theoretical model with the hierarchical regression method.

\section{SAMPLE}

We investigated the employees of 121 family enterprises in both developed areas of China, such as Beijing, Shanghai, Zhejiang, and Guangdong, and also less-developed areas, including Hunan, Hubei, Sichuan, and Guangxi. We obtained the information of these 121 family enterprises from the association of Chinese family enterprises. These family enterprises are private and small \& medium sized firms. Such a wide range of samples helped us to obtain a relatively holistic sample of Chinese family enterprises in such a large continental country. Initially, 3,900 questionnaires were distributed to the selected 121 family enterprises. In total, we received 2,625 answered questionnaires, a response rate of $67.3 \%$. The large geographic scope of our study is likely to represent a more balanced sample of Chinese family enterprises. The scope of the present study extends previous studies on Chinese family enterprises that had either focused on overseas locations such as Taiwan or had only focused on developed areas in China.

Males accounted for $53.5 \%$ of the respondents and females $46.5 \%$; the age groups of under 34,35 to 44 , and above 45 represented $72.6 \%, 20.7 \%$, and $6.6 \%$, respectively, of the sample; married people accounted for $57 \%$ of respondents, unmarried people $41.4 \%$, and divorced people $1.7 \%$. The core family staff members accounted for $3.1 \%$ of the sample, $6.8 \%$ were close relatives, $6.2 \%$ were distant relatives, $5.7 \%$ were friends, and $78.2 \%$ had no personal relationship with the family.

The respondents' career data was the following: people in management, administrative services, marketing, technology, and operation composed $21.3 \%, 11.3 \%, 18.3 \%, 25.3 \%$, and $23.8 \%$, respectively, of the sample. $72.2 \%$ of the respondents had worked in their enterprise for less than 5 years, $14.2 \%$ for 6-10 years, $5.1 \%$ for $11-15$ years, and $8.4 \%$ for 16 years or more.

Various enterprises were sampled. Those that had existed for less than 3 years, 3-5 years, 5-10 years, 10-20 years, and more than 20 years represented $16.7 \%, 13.1 \%, 33.5 \%, 16.7 \%$, and $19.9 \%$, respectively, of the sample. In terms of revenue, $38.0 \%$ of the enterprises had below 10 million CNY in annual revenue, $18.5 \%$ had between 10 million and 30 million CNY, $9.0 \%$ between 30 million and 50 million CNY, 2.8\% between 50 million and 80 million CNY, 7.5\% between 80 million and 100 million CNY, and $24.2 \%$ more than 100 million CNY.

\section{RELIABILITY}

For the purpose of scale development, principal components factor analyses with varimax rotation were performed on three sets of items: the 33 items related to job satisfaction, the 14 items describing turnover intention, and the five performance criteria. We adopted 33 items to assess job satisfaction (on a scale of $1-5$ with $1=$ strongly dissatisfied and $5=$ strongly satisfied). The turnover intention was measured with 14 items using a five-point Likert scale ( $1=$ strongly dissatisfied and $5=$ strongly satisfied). Performance refers to the productivity level of an individual employee. The questionnaire sought to study the worker's performance in family enterprises and was measured with five items using a Likert scale with $1=$ strongly dissatisfied and $5=$ strongly satisfied.

We used Cronbach's consistency (coefficient $\alpha$ ) to analyze reliability as shown in Table 1 . The alpha coefficients of the job satisfaction factors $1-7$ are $0.89,0.88,0.84,0.76,0.75,0.75$, and 0.68 respectively. These are all above 0.65 and show reliable internal consistency. We deleted the factor having overlapping load on the standard where the factor load is more than 0.5 .

We used Cronbach's consistency (coefficient $\alpha$ ) to analyze reliability as shown in Table 2. Cronbach's $\alpha$ of turnover intention for this scale was 0.93 and Cronbach's $\alpha$ of work performance for this scale was 0.87 .

\section{Results}

In Table 3, we report the descriptive statistics and correlations of all hypothesized variables and control variables. We can find almost all inter-factor correlations are below the threshold of 0.65 , except the inter-factor correlation between hierarchy and work position, which is 0.662 , and hierarchy and work performance, which is 0.682 . These two are slightly higher than the threshold. It suggests that our estimations are not likely to suffer from multicollinearity problems. Please note that the correlations of our independent variable to control variables are very low. As we take the industry (three different industries: the manufacturing, real estate, and information-technology industries) as a dummy variable, we did not include this control variable in the descriptive statistics in Table 3 but include it in the regression results afterward. Table 3

Table 4 shows the results of our hypothesis testing. We use the ordinary least square regression analysis to test all hypotheses. Model 0 is the base model, in which we control for gender, age, work position, hierarchy, and industry. In Model 1, we test the hypotheses $\mathrm{H} 1 \mathrm{a}$ and $\mathrm{H} 2 \mathrm{a}$. The results from Model 1 indicate that job satisfaction is negatively related to turnover intention $(b=-0.217, p<0.01)$ and positively related to work performance $(b=0.131, p<0.01)$. This means that our hypotheses H1a and $\mathrm{H} 2 \mathrm{a}$ are not rejected. Model 1 also shows that the moderating variables of family membership and managerial position are also significant. 


\begin{tabular}{|c|c|c|c|c|}
\hline \multicolumn{5}{|c|}{$\begin{array}{c}\text { TABLE } 1 \\
\text { Reliability for the Job Satisfaction }\end{array}$} \\
\hline Item & $\alpha$ & $\begin{array}{l}\text { Item-total } \\
\text { correlation }\end{array}$ & Loading & Contributor \\
\hline Factor 3: pay-and-benefits package & 0.84 & & & 4.465 \\
\hline V01 Personal wage income & & 0.641 & 0.684 & \\
\hline V02 Benefits package of the unit & & 0.632 & 0.636 & \\
\hline V03 Fairness of remuneration system of the unit & & 0.594 & 0.700 & \\
\hline V04 Rationality of remuneration system of the unit & & 0.578 & 0.700 & \\
\hline V05 Calculation mode of remuneration system of the unit & & 0.532 & 0.651 & \\
\hline V07 Proportion of remuneration (pay and benefits) & & 0.520 & 0.579 & \\
\hline V08 Recent distribution system of remuneration & & 0.497 & 0.625 & \\
\hline Factor 2: career development & 0.88 & & & 4.929 \\
\hline V10 Development of self knowledge and skills in company & & 0.512 & 0.656 & \\
\hline V11 Position promotion & & 0.653 & 0.729 & \\
\hline V12 Self-actualization of social value & & 0.642 & 0.705 & \\
\hline V13 Training system in company & & 0.613 & 0.683 & \\
\hline Factor 7: living condition & 0.68 & & & 2.851 \\
\hline V15 Sanitation in canteen and quality of the dishes & & 0.624 & 0.697 & \\
\hline V16 Accommodation arrangement & & 0.654 & 0.751 & \\
\hline Factor 4: working safety. & 0.76 & & & 4.107 \\
\hline V19 Medical security & & 0.654 & 0.741 & \\
\hline V20 Occupational injury insurance & & 0.662 & 0.760 & \\
\hline V21 Labor protection & & 0.651 & 0.748 & \\
\hline Factor 5: working hours & 0.75 & & & 3.623 \\
\hline V22 Working hours scheme & & 0.521 & 0.671 & \\
\hline V23 Regulation on time for rest & & 0.510 & 0.661 & \\
\hline V24 Regulation on overtime system & & 0.482 & 0.542 & \\
\hline V09 Vacation arrangement & & 0.493 & 0.578 & \\
\hline Factor 6: interpersonal relation. & 0.75 & & & 3.013 \\
\hline V26 Communication among colleagues & & 0.690 & 0.833 & \\
\hline V27 Interpersonal relation among colleagues & & 0.681 & 0.808 & \\
\hline V28 Cooperation \& collaboration among colleagues & & 0.651 & 0.691 & \\
\hline Factor 1: inner management & 0.89 & & & 34.413 \\
\hline V29 Continuity and stability of the management & & 0.492 & 0.522 & \\
\hline V30 Setup of the organization \& institution & & 0.502 & 0.597 & \\
\hline V31 Staffing system & & 0.523 & 0.617 & \\
\hline V32 Supervision system & & 0.483 & 0.573 & \\
\hline V33 Administrative ability of the executive personnel & & 0.546 & 0.636 & \\
\hline V34 Management measure of the executive personnel & & 0.572 & 0.684 & \\
\hline V35 Management efficiency of the executive personnel & & 0.592 & 0.695 & \\
\hline V36 Internal complaint handling & & 0.491 & 0.585 & \\
\hline V37 System construction & & 0.473 & 0.555 & \\
\hline V38 Attitude and principle in disposal of customer complaint & & 0.432 & 0.525 & \\
\hline
\end{tabular}

In Model 2, we evaluate the moderating effects of family membership (family members and non-family members within the family enterprise) on the main effect between job satisfaction and turnover intention, as well as the work performance. The results of Model 2 indicate that the effect of family membership positively moderates the correlation between job satisfaction and turnover intention $(b=0.129, p<0.05)$, and positively moderates the correlation between job satisfaction and work performance $(b=0.103, p<0.01)$. This shows that, for non-family members, the main effects between job satisfaction and turnover intention as well as work performance, are more significant than for family members. It indicates that our hypotheses $\mathrm{H} 1 \mathrm{~b}$ and $\mathrm{H} 2 \mathrm{~b}$ cannot be rejected. In Model 2, we also evaluate the effects of managerial position (ordinary employees or managers) in the two main effects and find that they are significant $(b=0.082, p<0.01$ for job satisfaction and turnover intention; $\mathrm{b}=0.106, \mathrm{p}<0.05$ for job satisfaction and work performance). This indicates that our hypotheses $\mathrm{H} 1 \mathrm{c}$ and $\mathrm{H} 2 \mathrm{c}$ cannot be rejected. This is to say that we estimate the interaction of family membership and managerial position in the two main effects and find that they are significant. 
Model 3 is our full model. We evaluate the moderating effect of managerial position on the interaction of family membership in the main effects. The results of Model 3 indicate that, for people with managerial positions, the moderating effects of family membership in the correlation between job satisfaction and turnover intention $(b=0.402, p<0.01)$, as well in the correlation between job satisfaction and work performance $(b=0.416$, $\mathrm{p}<0.01$ ), are higher. It shows that managerial position (ordinary employees or managers) positively moderates the moderating effects of family membership in the main effects. Therefore, our hypothesis H1d and $\mathrm{H} 2 \mathrm{~d}$ are not rejected.

In summary, we have found strong empirical support for our hypotheses: the main effect of $\mathrm{H} 1 \mathrm{a}$ and $\mathrm{H} 2 \mathrm{a}$; the moderating effect of family membership (family members or non-family members) on the main effect of $\mathrm{H} 1 \mathrm{~b}$ and $\mathrm{H} 2 \mathrm{~b}$; the moderating effect of managerial position (ordinary employees or managers) on the main effect of $\mathrm{H} 1 \mathrm{c}$ and $\mathrm{H} 2 \mathrm{c}$; and finally the moderating effect of managerial position in the moderated correlation of $\mathrm{H} 1 \mathrm{~d}$ and $\mathrm{H} 2 \mathrm{~d}$. Taken together, these results strongly indicate that family membership and managerial position of these employees or/and managers are important factors in the governance of Chinese family enterprises.

\section{Discussions and Conclusions}

This paper investigated and surveyed human resource management and corporate governance in Chinese family enterprises. Our work provides the following contributions. According to Whetten (1989, p. 493), "theoretical insights come from demonstrating how the addition of a new variable significantly alters

\begin{tabular}{|c|c|c|c|c|}
\hline \multicolumn{5}{|c|}{$\begin{array}{l}\text { TABLE } 2 \\
\text { Reliability for the Turnover Intention and Work Performance }\end{array}$} \\
\hline Item & $\alpha$ & $\begin{array}{l}\text { Item-total } \\
\text { correlation }\end{array}$ & Loading & Contributor \\
\hline Turnover Intention & 0.93 & & & 62.052 \\
\hline V01 stay for a long time in your current profession & & 0.787 & 0.785 & \\
\hline V02 change your current profession & & 0.721 & 0.775 & \\
\hline V03 enter another profession. & & 0.720 & 0.705 & \\
\hline V04 leave your company as soon as possible. & & 0.706 & 0.705 & \\
\hline V05 lack of interest in your work & & 0.685 & 0.684 & \\
\hline \multicolumn{5}{|l|}{ V06 keep your current job } \\
\hline V07 company is significant & & 0.678 & 0.684 & \\
\hline V08 feel like a family member in your family & & 0.654 & 0.658 & \\
\hline V09 feel strong sense of belonging to your company & & 0.570 & 0.645 & \\
\hline V10 have no other choice now. & & 0.521 & 0.556 & \\
\hline V11 others couldn't offer the treatment that you want. & & 0.482 & 0.537 & \\
\hline V12 leave your company now, you will get into trouble & & 0.462 & 0.509 & \\
\hline V13 resign now & & 0.512 & 0.460 & \\
\hline V14 you wouldn't have a good future if you stay in your company. & & 0.424 & 0.443 & \\
\hline Work Performance & 0.87 & & & 55.923 \\
\hline V01 relatively more excellent on work performance & & 0.7102 & 0.705 & \\
\hline V02 boss is satisfied with my work performance & & 0.6892 & 0.675 & \\
\hline V03 colleague always apprises my work performance & & 0.6461 & 0.676 & \\
\hline V04 work performance were excellent, always be praised & & 0.5807 & 0.586 & \\
\hline V05 guarantee both quality and quantity in my work & & 0.5790 & 0.575 & \\
\hline
\end{tabular}

\begin{tabular}{|l|c|c|c|c|c|c|c|c|c|}
\hline \multicolumn{7}{|c|}{ TABLE 3 } \\
\begin{tabular}{|l|c|c|c|c|c|c|c|}
\hline \\
\hline
\end{tabular} & M & SD & $\mathbf{1}$ & $\mathbf{2}$ & $\mathbf{3}$ & $\mathbf{4}$ & $\mathbf{5}$ & $\mathbf{6}$ & $\mathbf{7}$ \\
\hline 1. Gender & 1.341 & 0.482 & & & & & & & \\
\hline 2. Age & 34.753 & 7.121 & $0.384^{* *}$ & & & & & & \\
\hline 3. Work position & 9.652 & 7.374 & $0.186^{* *}$ & $0.190^{* *}$ & & & & \\
\hline 4. Hierarchy & 5.426 & 3.242 & $0.361^{* *}$ & $0.279^{* *}$ & $0.662^{* *}$ & & & & \\
\hline 5. Job satisfaction & 17.930 & 12.318 & $0.142^{* *}$ & $0.091^{* *}$ & $0.129^{* *}$ & $0.085^{* *}$ & & & \\
\hline 6. Work performance & 14.055 & 3.217 & $0.293^{* *}$ & $0.496^{* *}$ & $0.514^{* *}$ & $0.682^{* *}$ & $0.349^{* *}$ & & \\
\hline 7. Turnover intention & 16.735 & 5.068 & $0.285^{* *}$ & $0.317^{* *}$ & $0.197^{* *}$ & $0.216^{* *}$ & $-0.322^{* *}$ & $-0.279^{* *}$ & \\
\hline 8. Family membership & 5.733 & 1.069 & $0.048^{* *}$ & $0.071^{* *}$ & $0.059^{* *}$ & $0.061^{* *}$ & $0.139^{* *}$ & $0.211^{* *}$ & $0.206^{* *}$ \\
\hline
\end{tabular}

Notes: ${ }^{*} \mathrm{p}<.05 ;{ }^{* *} \mathrm{p}<.01$, two-tail test; all path coefficients are standardized. 
our understanding of the phenomena by reorganizing our causal maps." Hereby, we summarize the theoretical importance of family membership and managerial position in the governance and management of Chinese family enterprises. In this study, we conducted a survey of Chinese family enterprises to test our hypotheses empirically and achieved supported empirical results. In general, our study enriches agency theory and corporate governance literature in family enterprises, by providing new insights into family owners' value systems in the management of human resources. Through quantitative research of Chinese family enterprises, we provide details of the difference between family members and non-family members in the governance of family enterprises by closely examining the relationship between job satisfaction and turnover intention, as well as the correlation between job satisfaction and work performance.

More specifically, we find that the degree of job satisfaction affects the individual's turnover intention in Chinese family enterprises, for both family members and non-family members, regardless of their positions in the family enterprises. Our results of negative effects of job satisfaction on turnover intention are consistent to the established literature of corporate governance (such as Lee et al., 1999; Trevor, 2001; DeConinck and Stilwell, 2004). Although personal goals of family members may differ from those of non-family members, the long-termoriented goals of the business-owning families may provide more organizational supports to increase the job satisfactions of employees (Le Breton-Miller and Miller, 2006; Valentine et al., 2006; Block, 2010). In this case, the turnover intention of employees and managers in the family enterprises will be reduced. According to Maslow's hierarchy of needs theory (Wahba and Bridwell, 1976), smooth career development belongs to an individual's high-level demands. When the basic needs of family member employees' are satisfied, these employees begin to pursue opportunities for individual career development and can begin to realize value in their values.

In addition, we also find that a higher degree of job satisfaction leads to higher work performance for both family members and non-family members, regardless of whether they hold a managerial position in the family enterprises. Our results of positive influence of job satisfaction on work performance are consistent to some of the early empirical studies (such as Hochwarter et al., 1999; Judge et al., 2001). Our study also extends the findings of some other early studies in which researchers find no correlations between job satisfaction and work performance, such as the study of Brashear et al. (2003). However, we conduct our research in a specific type of firm, family enterprises, and conclude a positive role of job satisfaction in work performance for this kind of companies. Our results affirm that the correlation between job satisfaction and work performance is complex, and can be influenced by other factors such as role orientation, role overload and role ambiguity (Brashear et al., 2003; Jones et al., 2007). In family enterprises, it is complex to manage a group of family member employees, non-family member employees, family member managers and non-family member employees.

Our study also summarizes the importance of family membership and managerial position in the aforementioned two main effects governing family enterprises in China. It could be found that for family members, the correlation between job satisfaction and turnover intention and the relationship between job satisfaction and work performance are lower than

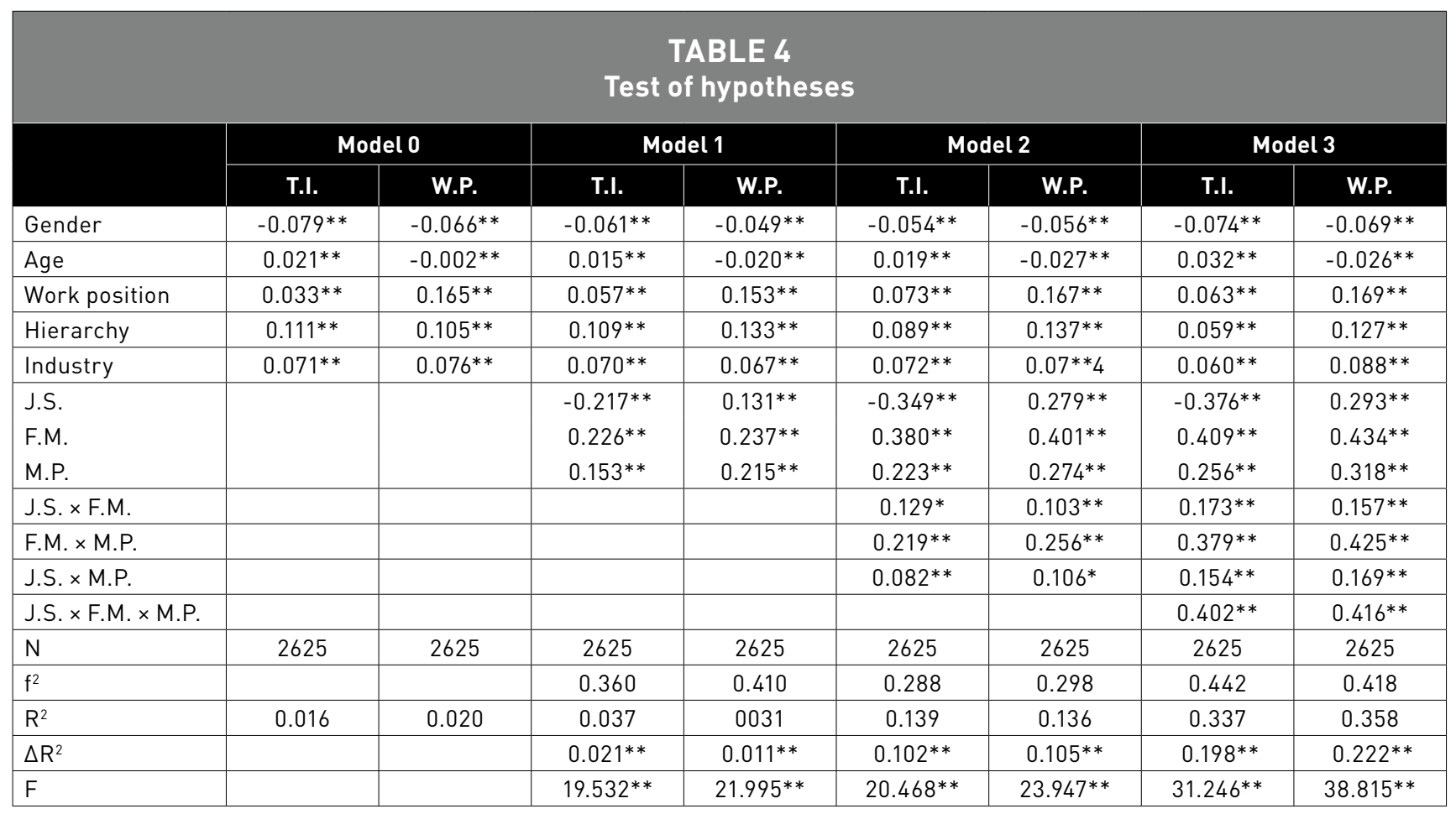

Notes: T.I.= Turnover intention, W.P.= Work performance, J.S.= Job satisfaction, F.M.= Family membership, M.P.= Managerial position

$*^{*}<.05{ }^{* *} p<.01$, two-tail test; all path coefficients are standardized.

F.M. (dummy): Family member=0, non-family member $=1$.

M.P. (dummy): Ordinary employee $=0$, manager $=1$. 
for non-family members. This is partially because of the family bonds within the family enterprises (Wong, 1985) and partially due to the potentially higher internal benefits for family members within the family enterprises (Khanin et al., 2012). However, family members also have choices to work for their family enterprises or to take the outside job. Comparing with non-family members, family members may have a divergent perception of their job, including the job satisfaction (Berrone et al., 2012). Therefore, some family members choose to work for their family enterprises or stay in those family enterprises, because their aspirations and ambitions can be better met (Khanin et al., 2012). Or it may be because family members can receive comparable higher returns with respect to the outside jobs (Sharma, 2004). In this case, comparing with non-family members, family members are less likely to consider leaving the family enterprises when the job satisfaction level is high. This finding is consistent to the early research of Sharma and Irving (2005) about the greater commitments of family members to their positions inside the family enterprises.

For managerial positions, our research also shows differences between ordinary employees and managers, in terms of the subjective perception of job satisfaction (Chua, Chrisman and Sharma, 2003). Our results summarize that for managers, the correlation between job satisfaction and turnover intention and the relationship between job satisfaction and work performance are higher than for ordinary employees. These can be understood from the perspectives of work stability, payment, personal identity, and social status (Sharma et al., 1997). Most often, companies credit managers more than ordinary employees for the enterprise's success. Such different attitudes and behaviors thus provide a better incentive mechanism and reduce the turnover behaviors of managers. In particular, for capable managers who are also family members, the potential high rewards will motivate them to remain working for family enterprises with higher performance (Tagiuri and Davis, 1996).

Our results also show that for managers, the moderation effects of family membership in the correlation between job satisfaction and turnover intention as well as work performance are higher than the effects for ordinary employees. In family enterprises, business owners have different expectations of family-member managers from those of the non-family member managers (Khanin et al., 2012). Therefore, managers, especially those family-member managers accept more challenges and have a greater sense of achievements in their daily activities (Sharma et al., 1997). That is to say, family-member managers can have stronger sense of engagements when working for their family enterprises. This leads to lower turnover intentions for family members occupying managerial positions. At the same time, staying within the family enterprises, those family-member managers will benefit more than working for outside employers (Sharma, 2004). These potential benefits thus motivate family-member managers to better manage their work activities and tasks. For family enterprises owners, knowing and understanding the difference between ordinary employees and managers in family enterprises is important. More importantly, integrating the employees and managers, regardless of their managerial position and family membership, is beneficial to the governance of family enterprises (Khain et al., 2012).
In addition to the aforementioned theoretical contributions, our study also has practical implications for decision-makers in family enterprises. First, the research provides further management insights for business practices in a transitional economy, where the future development of an enterprise is of greater concern to employees. Our study complements previous studies of Chinese family enterprises based on psychological theories, such as those by Zhu et al., (2012). An unstable organization faces difficulty in attracting and retaining talents. Inner management, a determinant for the future of enterprises, is a condition that keeps an organization competitive. A well managed company will enhance employees' confidence and loyalty, and inner management is the principal consideration for the enterprises in a transitional economy. Secondly, based on our results, ordinary employees are generally unsatisfied with their career development and interpersonal relations, which are critical in a transitional economy with rapid career changes. Some family enterprises always place their own "family members" or "insiders" in important positions but keep "non-family members" or "outsiders" away from managerial positions. In these family enterprises, the managerial position allocation is most often determined by nepotism (Lee, Lim and Lim, 2003). Thus, it is difficult for non-family members to participate in management and be promoted. Owners of Chinese family enterprises often consider staff training as a benefit provided by other companies that can be obtained from the talent spillover. As a result, there are few staff training activities and employees are less likely to be able to improve their professional skills in a family enterprise. A good balance between business and family interests is needed to guarantee a long-run personal career development (Khanin et al., 2012). After years of work, most managers have found work positions that are suitable for themselves, making them tend to be stable and unwilling to leave. Therefore, the turnover intention will vary significantly with managerial positions. As they are more familiar with their companies, senior managers are much more likely to achieve their goals in terms of remuneration and career development, which leads to higher satisfaction with the job, lowers their turnover intention, and enhances their work performance.

We admit that our study has limitations. First, our data are not longitudinal. Therefore, it is difficult for us to know how the relationship among job satisfaction and turnover intention, as well as work performance, evolves with time. Future research could focus on the evolution of governance in family enterprises in emerging economies. Second, we did not consider the detailed hierarchy of either family members or non-family members, such as the grades of top managers, middle managers, frontline managers, or operational staff. We understand that a top manager may perform differently from an ordinary employee in a family enterprise, regardless of family membership. Due to the limitation of information, however, we only differentiate ordinary employees from managers in our research. Therefore, we recommend more fine-grained studies that would consider the detailed hierarchical levels of the family members and nonfamily members in family enterprises. Third, we understand the challenges of generalizability based on the study of more recent and less-developed family enterprises. Therefore, we welcome comparisons of family enterprises in more-developed countries and those in other developing economies. 


\section{References}

Antia, M., Pantzalis, C. and Park, J. C. (2010). CEO decision horizon and firm performance: An empirical investigation. Journal of Corporate Finance, 16(3): 288-301.

Berrone, P., Cruz, C. and Gomez-Mejia, L.R., (2012). Socioemotional wealth in family firms theoretical dimensions, assessment approaches, and agenda for future research. Family Business Review, 25(3): 258-279.

BLocK, J. (2010). Family management, family ownership, and downsizing: evidence from S\&P 500 firms. Family Business Review, 23, 109-130.

Block, J.H. (2011), How to Pay Nonfamily Managers in Large Family Firms: A Principal-Agent Model, Family Business Review, 24 (1): 9-27

Brashear, T. G. White, E. and Chelariu, C. (2001). An empirical test of antecedents and consequences of salesperson job satisfaction among Polish retail salespeople. Journal of Business Research, 56 (12): 971-978.

Bray field, A.H. and Crockett, W.C. (1955). Employee attitudes and employee performance. Psychological Bulletin, 52(5): 64-73.

Carsten, J. M. and Spector, P. E. (1987). Unemployment, job satisfaction and employee turnover: a meta-analytic test of the Muchinsky model. Journal of Applied Psychology, 72(3): 199-212.

Chen, H.L and Zhou, F. (2003). Progress and Tendency of Research on Work Value Structure. Advances in Psychological Science,11(6): 700-703.

Chua, J. H., Chrisman, J. J., \& Sharma, P. (2003). Succession and nonsuccession concerns of family firms and agency relationships with nonfamily managers. Family Business Review, 16(2): 89-107.

DeConinck, J.B. and STILwelL, C.D. (2004). Incorporating organizational justice, role states, pay satisfaction and supervisor in a model of turnover intention. Journal Business Reviews, 57(3): 225-231

Demoussis, M. and Giannakopoulos, N. (2007). Exploring job satisfaction in private and public employment: Empirical evidence from Greece. Labour,21(2): 333-359.

Dienesch, R.M. and Liden, R.C., (1986). Leader-member exchange model of leadership: A critique and further development, Academy of Management Review, 11(3): 618-634

Dyer, W. G., Jr. (1989). Integrating professional management into a family owned business. Family Business Review, 2(3): 221-235.

Dyer, W.G., (2006). Examining the "family effect" on firm performance. Family business review, 19(4): 253-273.

Guzzo, R. and Аввотт, S. (1990). Family firms as utopian organizations. Family Business Review, 3(1): 23-33.

Hall, A. and Nordqvist, M. (2008), Professional Management in Family Businesses: Toward an Extended Understanding. Family Business Review, 21(1): 51-69.

HwANG, K.K., (2012). Guanxi and Organizational Behaviors in Chinese Society. In Foundations of Chinese Psychology (pp. 297-326). Springer New York.
IAFFALdANO, M. T. and MuChINSKy, P. M. (1985). Job satisfaction and job performance: a meta-analysis. Psychological Bulletin, 97, 251-273.

Jones, E., Chonko, L., Rangarajan, D., and Roberts, J. (2007). The role of overload on job attitudes, turnover intentions, and salesperson performance. Journal of Business Research, 60(7): 663-671.

Judge, T.A., Piccolo, R.F., Podsakoff, N.P., Shaw, J.C., and Rich, B.L. (2010). The relationship between pay and job satisfaction: A meta-analysis of the literature. Journal of Vocational Behavior, 77(2): 157-167.

Judge, T., Thoresen, C., Bono, J. and Patton, G. (2001). The job satisfaction-job performance relationship: A qualitative and quantitative review. Psychological Bulletin, 127(3): 376-407.

Khanin, D., Turel, O. and Mahto, R.V. (2012). How to Increase Job Satisfaction and Reduce Turnover Intentions in the Family Firm: The Family-Business Embeddedness Perspective. Family Business Review, 25(4): 391-408

Le Breton-Miller, I. and Miller, D. (2009). Agency vs. stewardship in public family firms: A social embeddedness reconciliation. Entrepreneurship Theory and Practice, 33(6): 1169-1191.

LEE, J. (2006). Impact of Family Relationships on Attitudes of the Second Generation in Family Business. Family Business Review, 19(3): 175-191.

Lee, T.W., Mitchell, T.R., Holtom, B.C., McDaneil, L.S. and HILL, J.W., 1999. The unfolding model of voluntary turnover: A replication and extension. Academy of Management journal, 42(4): 450-462.

LeE, K.S., Lim, G.H. and Lim, W.S., (2003). Family business succession: Appropriation risk and choice of successor. Academy of Management Review, 28(4): 657-666.

LeE, M. S. and Rogoff, E. G. (1996). Comparison of small businesses with family participation versus small businesses without family participation: An investigation of differences in goals, attitudes and family/business conflict. Family Business Review, 9, 423-437.

Li, P., Leung, K., Chen, C. and Luo, J.D., (2012). Indigenous Research on Chinese Management: What and How. Management and Organization Review, 8(1): 1 7-24

LI, X.X. and WANG, H.(2003). Task performance and performance factors performance verification of the mode. Chinese Journal of Management Science, (8): 79-84

Locke E A. (1969). What is Job satisfaction? Organization Behavior and Human Performance, 4(4): 309-336.

Margolis, R. and Myrskyla, M. (2011). A global perspective on happiness and fertility. Population and Development Review, 37(1), 29-56.

McNeilly, K. and Goldsmith, R.E. (1991). The moderating effects of gender and performance on job satisfaction and intentions to leave in the sales force. Journal of Business Research, 22(3): 219-232.

Millan,J.M., Hessels, J., Thurik, R.,\& Aguado, R. (2013). Determinants of job satisfaction: A European comparison of self-employed and paid employees. Small Business Economics, 40(3): 651-670. 
SCHWEPKer, C.H. (2001). Ethical climate's relationship to job satisfaction, commitment, job satisfaction, and turnover among psychiatric technicians. Journal Business Reviews, 54(1): 39-52

Sharma, P. (2004). An Overview of the Field of Family Business Studies: Current Status and Directions for the Future. Family Business Review. 17(1): 1-36.

Sharma, P., Chrisman, J.J. and Chua, J.H., (1997). Strategic management of the family business: Past research and future challenges. Family business review, 10(1): 1-35.

Shore, L. M. and Martin, H. J. (1989). Satisfaction and organizational commitment in relation to work performance and turnover intentions. Human Relations, 42(7): 625-638.

Sieger, P., Bernhard, F., and Frey, U. (2011). Affective commitment and job satisfaction among non-family employees: Investigating the role of justice perceptions and psychological ownership. Journal of Family Business Strategy, 2(2): 78-89.

Spector, P.E., (1997), Job Satisfaction: Application, Assessment, Causes, and Consequences, SAGE Publications, London.

TAgiURI, R. and DAVIS, J., (1996). Bivalent attributes of the family firm. Family business review, 9(2): 199-208.

Trevor, C.O. (2001). Interaction among actual ease of movement determinants and job satisfaction in the prediction of voluntary turnover. Academy of Management Journal, 44(4): 621-638
Valentine, S., Greller, M.M. and Richtermeyer, S.B. (2006). Employee job response as a function of ethical context and perceived organization support. Journal of Business Research, 59(5): 582-588.

WAHBA, M.A. and BRIDWELL, L.G., (1976). Maslow reconsidered: A review of research on the need hierarchy theory. Organizational Behavior and Human Performance. 15(2): 212-240.

WANous, J.P. (1974). Individual difference and reaction to job characteristics. Journal of Applied Psychology, 59(5): 616-622.

Whetten, D.A. (1989). What Constitutes a Theoretical Contribution? Academy of Management Review, 14(4): 490-495.

Wong, S.L., (1985). The Chinese family firm: A model. British Journal of Sociology, pp.58-72.

Yu, H.B and Zhang, D.J. (2001). A Preliminary Study on the Vocational Value of Normal College Students. Journal of Southwest China Normal University, 27(2): 61-66.

Zhang, H. (2005). Development report of Chinese family enterprises 2004, Beijing. Social Science Literature Publishing House.

Zhu, H., Chen, C., Li, X.C. and Zhou, Y.H., (2012). From Personal Relationship to Psychological Ownership: The Importance of Manager-Owner Relationship Closeness in Family Businesses. Management and Organization Review, 9 (2): 295-318. 